\title{
維持透析中に精神障害を再発した患者の看護 一愛知県下における精神障害合併患者の実態調査一
}

\author{
松本ひろ子澤中王美河合道代石川 友紀子 \\ 板 倉 芳子 上田 真紀子 長谷川 広重宗 宮 信 賢 \\ 両角 國 男* \\ クリニックつしま 名古屋市立大学第 3 内科*
}

key words：精神障害合併維持透析患者，アンケート解析，地域診療支援システム，リエゾン精神医学

〈要旨〉

精神障害の再燃にて精神科病院へ入院治療を必要とした症例の治療過程に生じた問題への対処を契機に, 愛知県 下における維持透析患者で入院を要すると考えられた精神障害患者の受け入れ, 治療実態に関するアンケート調査 を実施した。ここに報告する。

症例は 50 歳，男性，透析歴 12 年の維持透析患者で，非定型精神病の再燃にて入院を必要とした。透析可能な精 神科病棟を有する総合病院への転院ができず，やむを得ず精神科単科病院に入院した．当院の職員 2 名で送迎を行 い，通院透析を行った，透析中は専任ナースを配置するなどの工夫を行った，幸い非定型精神病は治まり，約 3 か 月後に退院した。

この症例のような入院治療を要すると考えられる精神症状を有した透析患者の実態を調査するために，愛知県下 の透析施設に同様な経験の有無と入院の有無，転院時に生じた問題，および，具体的対処に関するアンケート調査 を行った. アンケートは愛知県内の 111 施設に郵送で行い, 72 施設 $(65 \%)$ より回答を得た. 4,418 名中 62 名 (1.4\%) の精神障害者が存在した。透析患者に認められた精神科病名は, 躁うつ病 (24 名), 分裂病 (14 名) が多く, 次い で老人性痴呆であった，年齢と疾患の関係では，精神障害合併患者は 50 歳代に最も多く，兰の殆どが躁うつ病と分 裂病であった。

精神障害を有する患者 62 名のうち入院適応と診断された患者は 20 名で $32 \% に$ に相当した。要入院の 20 名中 17 名 （85\%）は入院可能であった。 弚の治療形態は，精神科病棟に入院し治療が行われたのは 17 名中 11 名 (65\%) であ り, 入院中の同一施設内での透析が可能だったのは, 11 名中 5 名のみであった. 残りの 6 名は他施設にて透析を行っ ていた，精神科病棟に入院できなかった 6 名の患者は透析可能な一般病棟へ入院，治療を行った。向精神薬の投与 は維持されたが，一般病棟であるため，夜間の不穏やせん妄に対する緊急処置や行動管理の面での問題が指摘され た。入院治療が必要とされた 20 名中 15 名 $(75 \%)$ の殆どの症例で，入院待ち期間が，非常に長かった。入院となっ ても手続きや 2 施設間の搬送に伴う責任の所在など，いくつかの障壁が指摘された．同一施設内での総合治療が望 まれるが, 現実には総合病院で精神科病床を有するところは極めて少なく, 受け入れも困難であることがわかった.

今後，広域での透析施設間の情報交換や，精神科との連携診療を密にすることが必要と思われた。

A study on the medical social circumstances of uremic patients on maintenance hemodialysis complicated with psychosis; A case study and the analysis of questionnaire results in Aichi prefecture

Hiroko Matsumoto, Tamami Sawanaka, Michiyo Kawai, Yukiko Ishikawa, Yoshiko Itakura, Makiko Ueda, Hiroshige Hasegawa, Shinken Sohmiya, Kunio Morozumi*

Clinic Tsushima and Division of Hemodialysis, Nagoya city University Medical School*

The patients with end-stage renal disease on maintenance hemodialysis occasionally develop serious concomitant diseases which require hospitalization. The incidence of psychosis seems to be slightly increased in patients

松本ひろ子 クリニックつしまテ496-0019 津島市百島町黒仏二(0567-28-7111)

Hiroko Matsumoto Fax 0567-28-5250

〔受付：平成 9 年 5 月 2 日, 受理 : 平成 9 年 11 月 28 日〕 
on maintenance hemodialysis. One hemodialysis patient with recurrence of atypical psychosis was admitted to a psychiatric ward. We encountered great difficulty in making arrangements for admission to a general hospital with both an isolation ward for psychotic patients and a hemodialysis center. The patient was finally admitted to a professional psychiatric hospital located one hour by car from our hospital, and hemodialysis treatment was carried out at the out-patient clinic in our hospital. Two nursing staff accompanied him on the way to and from our hospital.

A questionnaire surveying the circumstances of hospitalization for patients with concomitant end-stage renal disease and psychosis was sent to all hemodialysis units in Aichi prefecture. The questionnaire inquired reqarding the prevalence and type of psychoses encountered during the last one year, the inevitability of hospitalization, problems in the process of admission and the consequences, problems during hemodialysis treatment and nursing plans. Responses were collected from 72 (65\%) of 111 hospitals. Among 4,418 uremic patients, 62 patients (1.4\%) with psychosis were enrolled in the analysis. The most common psychosis was manic-depressive illness $(n=24)$, and the second most common was shizophrenia $(n=14)$ and the third was senile dementia. Regarding age distribution in uremic patients with psychosis, the highest prevalence was found among those in their fifties. Hospitalization was indicated in 20 (32\%) of 62 psychotic patients. Only five patients were admitted to a general hospital where professional treatment in a psychiatric ward and hemodialysis were both available in the same hospital. Fifteen (75\%) of 20 patients had several problems in the process of admission. Six patients were admitted to a professional psychiatric hospital, and had to be transported to other hospitals as outpatients for hemodialysis. Six other patients were admitted to ordinary wards in hospitals without professional psychiatric ward. The remaining three patients were not admitted to any hospital. Several nursing plans; isolation, sedation during hemodialysis, restriction, attendance by family and/or an exclusive nursing staff and so on, were necessary for safe hemodialysis treatment.

A regional network is urgently needed to provide optimal therapy for hemodialysis patients with serious complications including psychosis.

\section{緒言}

透析患者は社会生活の上でも心身の両面でもストレ スが多く, 精神的な問題を生じやすいといわれている。 こうした精神的問題に対処するには，リエゾン精神医 学の重要性が最近強調されている1).

今回, 我々は精神科への入院を必要とした維持透析 患者の総合的な治療を試みたが，転院，連携などの面 でいくつかの問題を認めた。このような精神障害合併 透析患者の問題を透析施設共通の問題として捕える必 要性を感じ, 愛知県の現状を把握したいと考え, アン ケート調査を行ったので報告する。

\section{I 。症例}

50 歳, 男性, 家族構成は両親，実の妹，娘 2 人との 6 人暮らし, 妻は 13 年前に産裖うつ病 (?) にて死亡。 原疾患は慢性系球体腎炎, 24 歳でネフローゼ症候群を 指摘され, 14 年間保存療法を行うも限界となり, 38 歳 にてシャント造設, 同年 7 月某大学病院にて血液透析 導入となる. その後サテライトセンターに転院し, 維 持透析中であったが特定ナースに対し強い関心を示す ため, 47 歳, 当院に転院となる.
転院時サマリーには精神障害の既往の記載はなく, 転院時にもコミュニケーションは普通に図れ，意志の 疎通に問題はなかった。 今回の再発をきっかけに患者 や家族の情報より非定形精神障害の既往が明らかと なった。それによると，24歳，ネフローゼ症候群の治 療のため, 入院，ステロイド剤の投与中に幻覚が出現 した。精神科へ転科し向精神薬が投与された。 20 数年 前のため, 資料不足により詳細は不明. 3 か月間の治療 後退院, 退院後も精神症状の増悪により入退院を繰り 返していたが，その後外来通院となり，5～6 年間内服 治療を行う。その後自己判断にて内服中止していた。

38 歳にて透析導入となるが，導入直後および，維持 透析への移行後も不穏, 不安症状はなく多少多弁では あったが社会復帰しており，意志の疎通も充分はかれ ていた，体重管理，自己管理はきちんと行われ，特に 問題は生じていなかった。

\section{1. 今回の精神症状再燃後の経過}

表 1 にこの間の経過と治療および看護についてまと めた。平成 7 年 4 月上旬より，仕事上の問題や娘の教 育問題から情緒不安定となり透析中多弁, 独語, 他の 患者への暴言や一点を見つめていたり，突然起き上 がったりといった行動が目立つようになり，通院困難 となったため, 当院へ入院した，Thioridazine hydrochloride(メレリル $10 \mathrm{mg}$ ) 3 錠 $3 \times \mathrm{N}$, brotizolam (レ 
表 1 経過および看護

\begin{tabular}{|c|c|c|}
\hline 時 期 & 経 過 & 治療・看護 \\
\hline H7。 4 月上旬 & $\begin{array}{l}\text { 仕事上および娘の問題から不穏状態と } \\
\text { なり多弁, 独語, 他の患者への暴言が } \\
\text { みられるようになる. } \\
\text { HD 中興奮状態, 体動激しい }\end{array}$ & $\begin{array}{l}\text { 患者の話に耳を傾け，肯定，否定をしない。 } \\
\text { 他患者への説明を十分にした。 } \\
\text { 家族の協力を得た。（付き添い，送迎） }\end{array}$ \\
\hline $\begin{array}{r}\text { H7. } 4 \text { 月 } 19 \text { 日 } \\
22 \text { 日 }\end{array}$ & $\begin{array}{l}\text { 精神症状悪化, 通院困難, 当院入院 } \\
\text { 精神科クリニック受診（入院治療必要 } \\
\text { と診断される） } \\
\text { 総合病院および精神科に近い HD 施 } \\
\text { 設への転院を試みるがすべて断られ } \\
\text { る. } \\
\text { 看護婦への暴力をふるう, 他患への暴 } \\
\text { 言, 俳徊 }\end{array}$ & 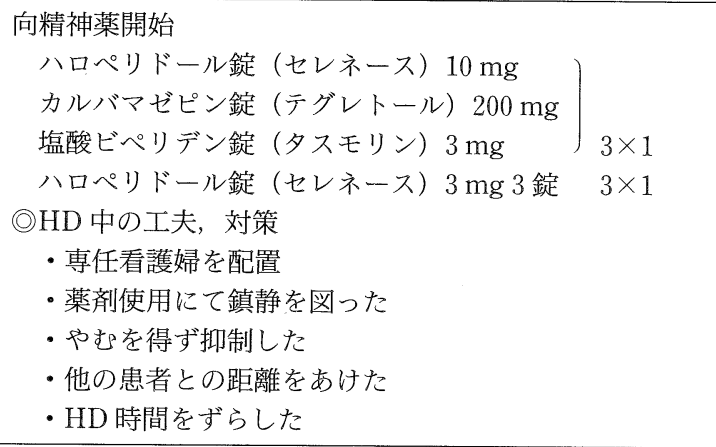 \\
\hline H7. 4 月 28 日 & $\begin{array}{l}\text { 精神科へ転院, HD は当院へ外来通院 } \\
\text { となる (CT 上器質的疾患は否定) } \\
\text { 多弁, 独語, 暴力行為徐々に治まる }\end{array}$ & $\begin{array}{l}\text { 週 } 3 \text { 回当院スタッフ } 2 \text { 名による送迎 } \\
\text { 精神科との連絡を密にするため, 連絡ノートを活用 } \\
\text { 服薬確認（向精神薬） } \\
\text { ○HD 中の工夫，対策を継続 }\end{array}$ \\
\hline $\begin{array}{r}\text { H7. } 5 \text { 月 } 17 \text { 日 } \\
18 \text { 日 }\end{array}$ & $\begin{array}{l}\text { 当院へ転院 } \\
\text { 洞機能不全症候群にて体内式ペース } \\
\text { メーカー植え込み術を施行 } \\
\text { ・心機能問題なし } \\
\text { 不穏, 不安なく安定 }\end{array}$ & $\begin{array}{l}\text { 術後管理の徹底（モニタリング，安静度） } \\
\text { 精神科との連絡，情報交換 }\end{array}$ \\
\hline H7. 6 月 8 日 & $\begin{array}{l}\text { 当院退院 } \\
\text { 同時に精神科も通院となる (1 回/1 週 } \\
\text { 父の送迎で外来受診) } \\
\text { ・HD 中トラブルなし }\end{array}$ & $\begin{array}{l}\text { 向精神薬内服続行 } \\
\text { 精神科, HD への送迎は父親 } \\
\text { ○HD 中の工夫，対策を徐々に緩和 }\end{array}$ \\
\hline H8. 4 月 & $\begin{array}{l}\text { 職場への復帰 } \\
\text { 精神科受診 } 1 \text { 回/月 本人運転 }\end{array}$ & $\begin{array}{l}\text { 向精神薬減量, 内服自己管理 } \\
\text { ハロペリドール錠（セレネース） } 7 \mathrm{mg} \\
\text { カルバマゼピン錠（テグレトール） } 150 \mathrm{mg} \\
\text { 塩酸トリヘキシシフェニジル錠（アーテン） } 5 \mathrm{mg} \\
\text { エチゾラム錠（デパス） } 1 \mathrm{mg}\end{array}$ \\
\hline
\end{tabular}

ンドルミン $0.25 \mathrm{mg}) 1$ 錠 $1 \times$ 眠前を使用するが，殆 ど効果なく不穏状態が続いた。透析中は安全に 4 時間 の透析が行えるように不穏時や体動が激しい時は haloperidol (セレネース注射液) を筋注し鎮静を図っ た。

症状の改善みられないため, 精神科クリニックを受 診. 非定形精神病と診断され, haloperidol (ハロステ ン $2 \mathrm{mg}$ ） 3 錠, biperiden（タスモリン $1 \mathrm{mg}$ ） 3 錠, mosapramine hydrochoride (クレミン $10 \mathrm{mg}$ ) 3 錠 $3 \times \mathrm{N}$, ベゲタミン-B 1 錠, flunitrazepam (ロヒプ ノール $1 \mathrm{mg}) 1$ 錠 $1 \times$ 眠前が好方された。精神科病棟 に入院し同一施設内での透析が望ましいと精神科医の コメントがあり，また，症状も軽減することなく，時 折スタッフに対し暴力をふるう, 他患への暴言や無断 訪室も頻回となった。当院での入院治療継続は困難と 考え, 総合病院または, 精神科に近い透析施設への転 院を試み，数箇所の施設に問い合わせをしたが，すべ
て断られてしまった，最終的に当院より車で 1 時間ほ どの精神科に受け入れが可能となり，転院. Haloperidol(セレネース) $10 \mathrm{mg}$, carbamazepine(テグレトー ル) $200 \mathrm{mg}$, biperiden (タスモリン) $3 \mathrm{mg} 3 \times \mathrm{N}$, levomepromazine (ヒルナミン) $25 \mathrm{mg}$, flunitrazepam （ロヒプノール） $1 \mathrm{mg} 1 \times$ 眠前が処方された。

透析治療は当院以外では不可能であったため, 当院 に通院して透析を行うこととなった。週 3 回当院の専 用車にて送迎を行った。 スタッフ 2 名を同乗させ暴力 や事故の防止に努めた。透析中は不穏状態なく傾眠傾 向であった，非透析日の精神科での状態および，透析 中の状況については, 連絡ノートや電話にて連絡しあ い，患者の情報伝達を行った。約 1 か月後には多弁さ や攻撃性は治まり，対応はスムーズに行えるように なった。しかし, 向精神薬の副作用による洞機能不全 症候群にて体内式ペースメーカーが必要となり当院へ 転院し，体内式ペースメーカー植え込み術を行った。 
表 2 アンケート内容

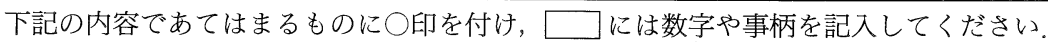

【1】 (1) 現在及び過去 1 年以内で精神病（精神科医の診断を受け明らかな病名が付いた）末期腎不全患者さんはいましたか?

(2)「はい」の場合 その患者数は何人ですか？

精神科病棟へ医学的入院が必要となった患者数は何人ですか?

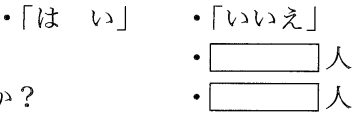

(3) それぞれ性別・年齢・発症時期・病名・入院について表にご記入ください.

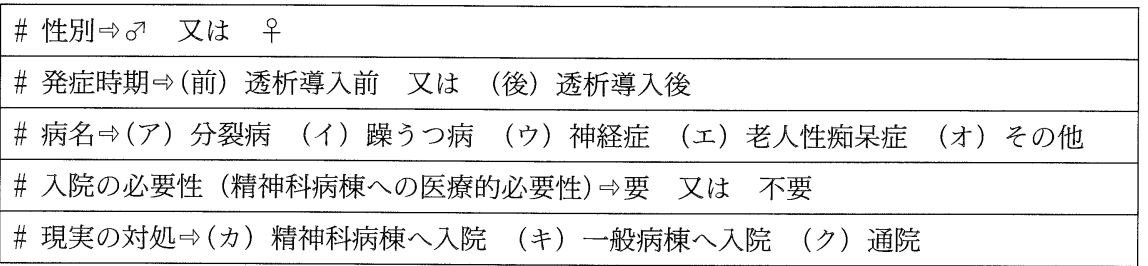

【2】(1) 入院治療を必要とする患者が出現したことで困難が生じましたか?

(2)「はい」の場合該当するすべてに○印を付けてください.

•「はい」・「いいえ」

その他の場合は $\square$ に記入してください

・透析と精神科治療を共に受けられる施設への転院ができなかった。

・精神科病棟への入院はできたが, 透析は当院へ通院してもらった.

・当院へ入院してもらい，精神科へは通院してもらった。

・透析施設及び精神科病棟への入院はできず，共に通院してもらった。

・ その他

【3】精神病を伴う患者さんについて

(1) 透析中に問題やトラブルは生じましたか？ ・「はい」

$$
\text { ・「いいえ」 }
$$

(2)「は」の場合 その際行った看護行為(工夫，対策 etc) は，ぞのようなものでしたか？ 該当するものすべてに○印を付けてください. その他の場合は $\square$ に記入ください.

・透析中やむを得ず抑制した。（安全の確保/危険防止）

・薬片を使用した。 (鎮静/入眠)

・専任看護婦を付き添わせた（全治療時間の専任/一部治療時間の専任）

・他の患者との距離をあけた。（Bed を離し本人の安静と他患の不安防止を図る)

・時間をずらして行った。/特別勤務体制をとった。

・ その他

【4】差し支えなければ貴院についてお答え願います。

(1) 貴院は何れに該当しますか?

(2) 透析専門施設ですか?
(3) 入院施設はありますか?

（国立市立 公立 私立）

・「はい」・「いいえ」

(4)「は い」の場合

・「はい」・「いいえ」

・総入院病床数は何床ですか?

・透析患者数は何名ですか?

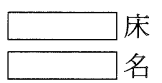

(入院/通院含めて)

(5) 貴院は総合病院ですか？・「はい」・「いいえ」

(6) 精神科はありますか？・「はい」・「いいえ」

(7) 精神科病棟はありますか？・「はい」・「いいえ」

(8)「は」の場合 その収容数は何床ですか？

精神科より, haloperidol（ブロトポン注射液）を前処 置や不穏時に使用するように助言された。 3 か月後に は不穏, 不安症状も落ち着き，心機能も安定していた ため, 当院退院と同時に精神科も通院治療となった。

1 週に 1 回父親の運転で外来受診. Haloperidol (セ レネース) $20 \mathrm{mg}$, carbamazepine (テグレトール) 300 mg, biperiden (タスモリン) $3 \mathrm{mg} 3 \times \mathrm{N}$, levomepromazine (ヒルナミン) $25 \mathrm{mg}$, flunitrazepam (ロヒ プノール） $1 \mathrm{mg} 1 \times$ 眠前を内服治療していた.
徐々に受診回数は減り，月 1 回受診となった. 向精 神薬は減量され，1年後には職場復帰することができ た。現在は 1 か月 1 回自分の運転で精神科受診し, haloperidol (セレネース) $7 \mathrm{mg}$, carbamazepine（テ グレトール) $150 \mathrm{mg}$, trihexyphenidyl hydrochloride (アーテン) $5 \mathrm{mg}$, etizolam (デパス) $1 \mathrm{mg} \quad 3 \times \mathrm{N}$ を 内服治療中である。 
表 3 アンケート結果

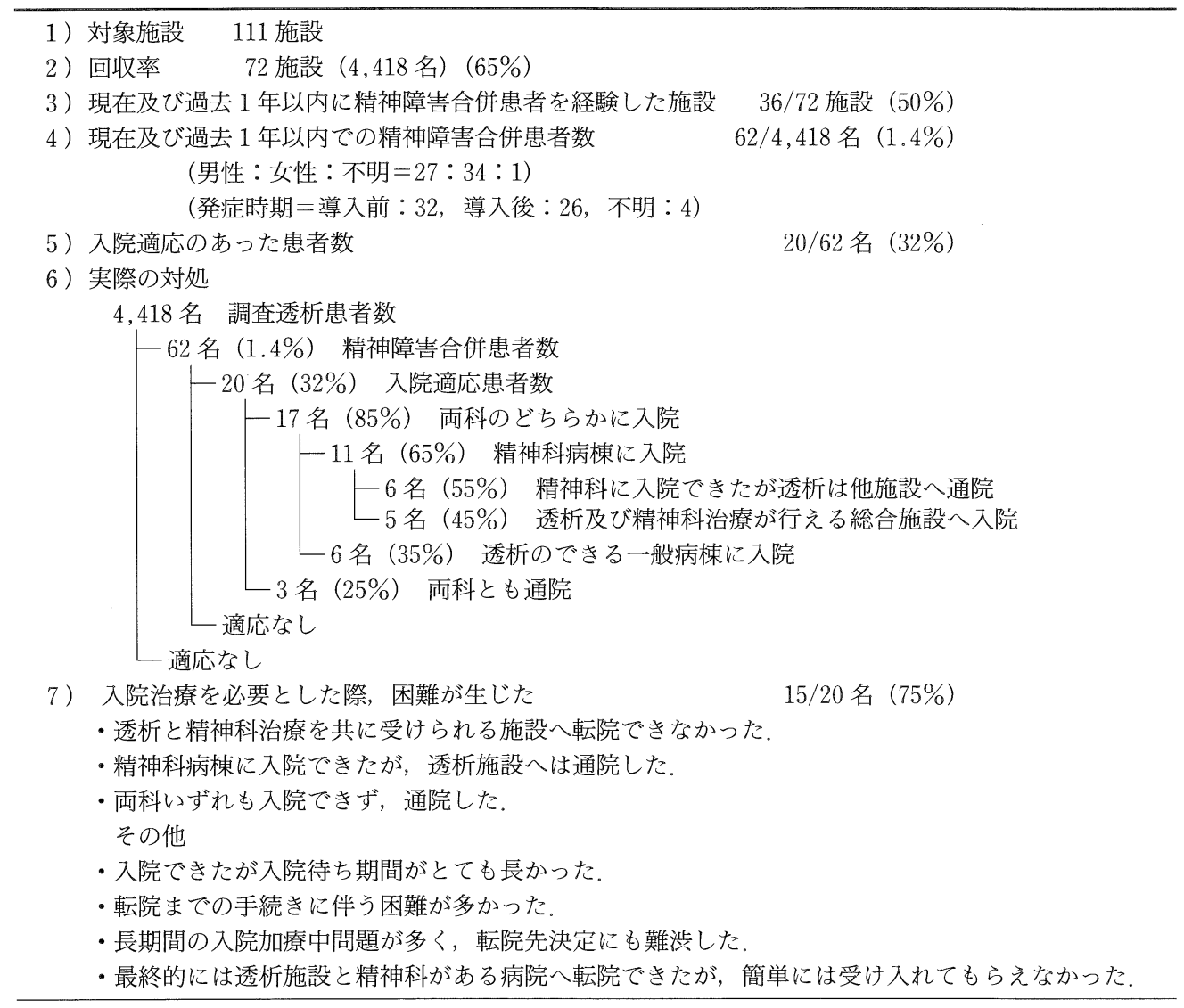

表 4 治療中の問題と看護行為の工夫

治療中に生じた問題

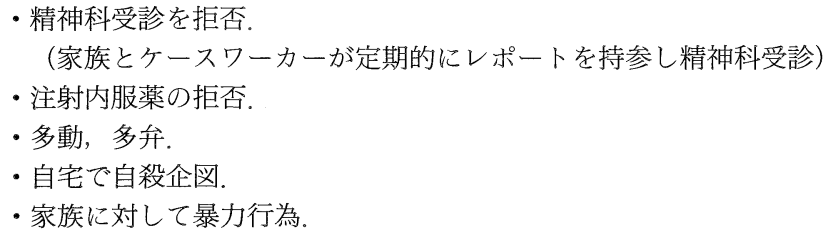

\begin{tabular}{|c|c|}
\hline 透析中行った看護行為, 工夫, 対策 & \\
\hline 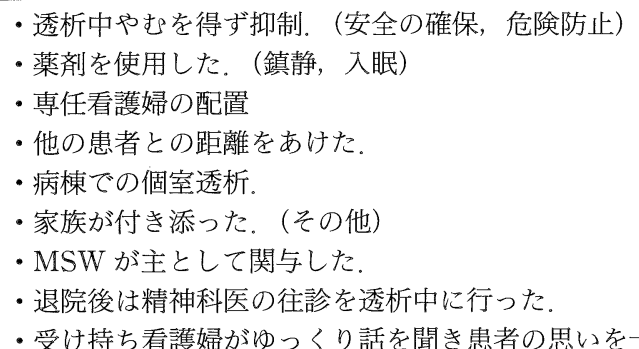 & $\begin{array}{r}13 \text { 件 } \\
15 \text { 件 } \\
8 \text { 件 } \\
4 \text { 件 } \\
1 \text { 件 } \\
1 \text { 件 }\end{array}$ \\
\hline
\end{tabular}

\section{2. 愛知県下における精神障害合併透析患者の実態に 関するアンケート調査}

精神障害を有する透析患者の現状を把握するため, 県下の全透析施設を対象にアンケート調査を行った。 送付したアンケート用紙を表 2 に示す。アンケート は 111 施設に郵送し， 72 施設 $(65 \%)$ より回答を得た。
アンケート結果の内容を表 3 , 表 4 に示す. 現在およ び過去 1 年以内に，精神障害合併患者を経験した施設 は，72 施設中 36 施設 (50\%) であった。精神障害合併 患者数は 4,418 名中 62 名 (1.4\%) であった。

入院の適応とされた患者数は 20 名 $(32 \%)$ であり， そのうち 17 名が入院していた。さらに検討すると, 精 


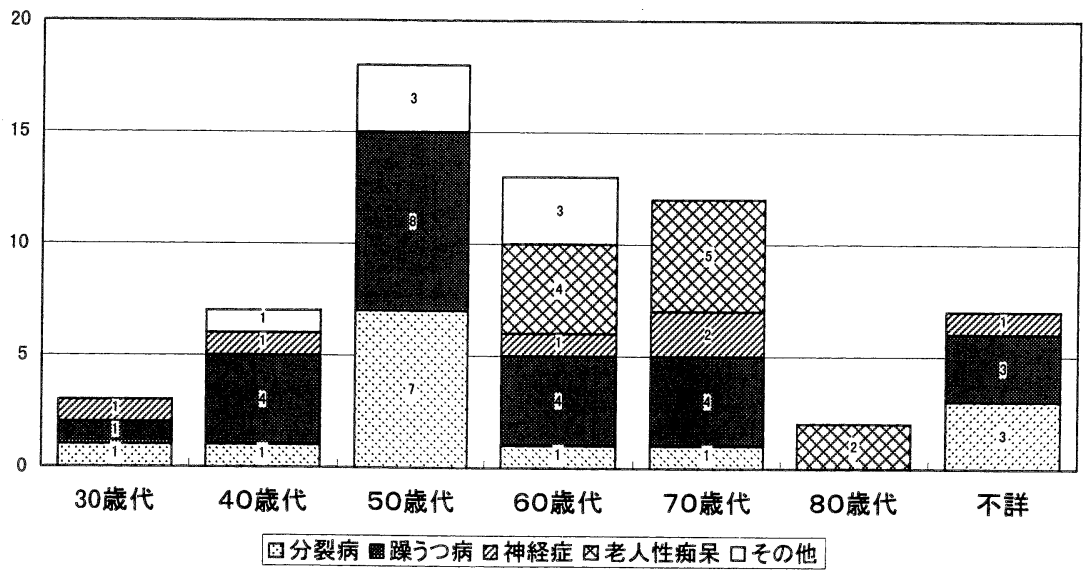

図 1 年齢と疾患との関係

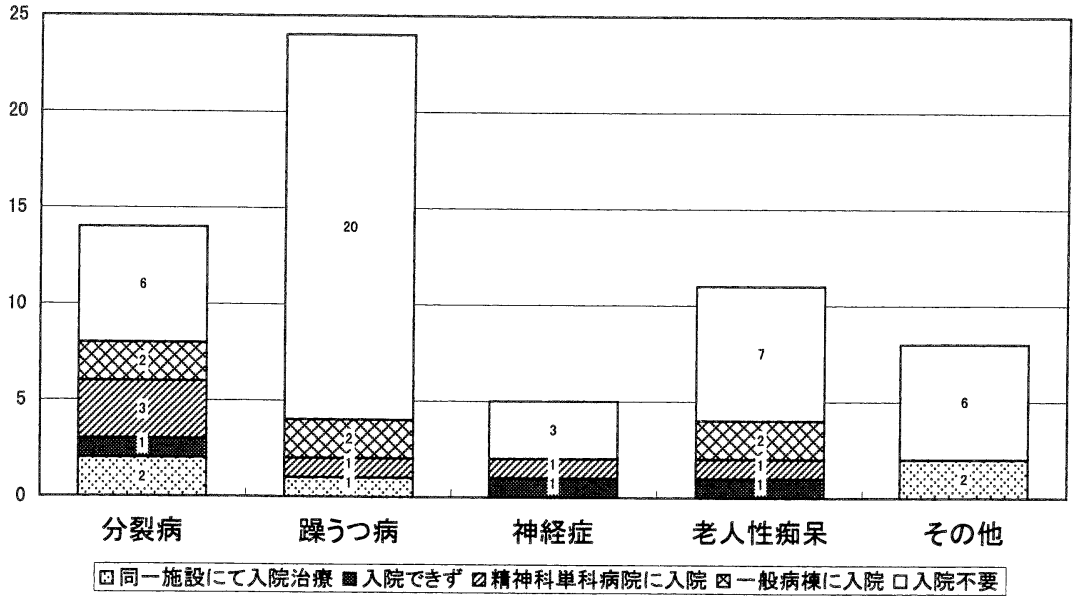

図 2 各疾患と入院との関係

神科病棟に入院できたのは 17 名中 11 名 $(65 \%)$ であ り，そのうち，同一施設内での透析が可能だったのは， 11 名中 5 名とごく僅かであり, 残り 6 名は精神科単科 病棟に入院し他施設にて透析を行った。その他の 6 名 の患者は透析可能な一般病棟へ入院し, 精神科の治療 を受けていた。 入院不能で精神科治療も透析も通院で 行ったのは 20 名中 3 名（15\%）であった。

各疾患と入院との関係を比較検討した（図 1 )。疾患 別にみると, 躁うつ病 24 名, 分裂病 14 名, 次いで老 人性痴呆 11 名となっており, 高齢化社会を反映してい た。その中で入院治療を必要とされたのは，分裂病 8 名, 躁うつ病 4 名であった，入院施設は図のごとくで 実際に総合病院に入院し同一施設にて入院治療ができ たのは, 分裂病 2 名, 躁うつ病 1 名であった。

年齢と疾患の関係をみた (図 2 )。精神障害合併患者 は 50 歳代に多く, その殆どが分裂病と躁うつ病で占め られていた。 60 歳以降では, 老人性痴呆が多くみられ た。

表 3 の入院に伴う困難の事例に示すように, 多くの
透析施設では, 精神障害者への対応は極めて難しい状 況におかれていた。入院を要する精神障害を合併した 患者の治療中の問題と看護行為の工夫を表 4 にまとめ た。実際生じた問題では，自宅での自殺企図や家庭内 暴力, 治療拒否等の精神科医の援助と精神科病棟への 収容が望まれる事実も多く存在していた。

透析中行った看護上の工夫, 対策は当該患者の安全 確保や危険防止を図るのは勿論, 他の患者の不安軽減 など，透析施設全体の運営が円滑に行われることを目 的とした。 そのために勤務体制の変更やシフト変更等 を行うことで対処されていた。

\section{II. 考察}

精神障害者が透析治療を継続する場合の看護の要点 は，患者の安全を第一に考えるのは勿論，当該患者が その透析施設で他の患者やスタッフに受け入れられる ような看護面での適切なアプローチが重要である。基 本的には一般の透析患者の看護と変わりはないが, 著 
しく人格変化をきたした患者の透析治療には，他の患 者への配慮等も必要となり，いずれの施設においても 患者を含めた全体の安全の確保と円滑な運営の工夫に 重点が置かれていた。

透析患者の高齢化に伴い，脳血管性痴呆透析患者の 増加とその評価, 対策は重要な課題である ${ }^{2)}$. 今後は増 加傾向にあると考元られる老人性痴呆患者の透析看護 体制の確立と, 精神障害をもつ患者の再発防止と, 再 発時のより良い対応のためには, 精神疾患の専門知識 をもつスタッフやメディカルソーシャルワーカー, ま たはカウンセラーといった他の職種間の援助や，精神 科専門医との協力や連携が必要と考えられる。また, 精神科医の治療への直接参加は重要であり, 例えば, 精神分裂病を有した透析患者の導入も継続的な精神科 医の加療により, 円滑に行えたとの報告もある ${ }^{33}$.

慢性維持透析療法を受けている患者のうち精神障害 合併患者は老人性痴呆を含めるとかなりの数が推定さ れるが, 明確な数值は明らかではない. 特に脳血管障 害浪伴う精神心理学的問題として, 性格の尖鋭化と痴 呆は, 重大な問題となっている4).

高齢透析患者の増加が挙げられる中, 高龄者の精神 医学的問題がクローズアップされつつあるが，その治 療, 看護は確立されていない, 精神科の通院治療を受 けながら, 透析施設へ通院する比較的安定した透析患 者の看護についても多くの課題があり，その看護上の 対策も報告されている5 ${ }^{5}$. しかし, 精神障害を有する透 析患者に対するリエゾンコンサルテーションを定期的 に行える透析施設は，少ないと考えられる，そうした 施設では, 患者に精神的問題が生じても, 最初にその 異常を知る看護婦が, 直接精神科医にコンサルテー ションする機会は得がたい゙(

今回我々は 1 症例をきっかけに, 愛知県における透 析患者の精神障害有病率の実態を把握したいと考元, アンケート調査を行い, 精神障害合併患者が予想以上 に多いことが判った。

維持透析施設には, 透析単科施設も多く以前より要 入院患者への対応が重要な課題であった。精神障害患 者に扔いては,さらに困難な問題が認められる. 今回, 我々の対応では送迎中の事故に対する責任の所在など 双方での話し合いがなされないままに行われた，現時 点で振り返ると大きな問題が検討されないまま行われ ていたなど, 多くの問題を認めた。また, 精神科スタッ フとのコミュニケーションが充分に図れず情報伝達シ ステムがうまく機能しなかった。 今後, この経験を活 かし同様の精神障害を有する透析患者への対処時には 改善をしたい.
精神障害合併患者の入院治療は, 同一施設内での総 合治療が望まれるが，実際には極めて困難で，受け入 れ施設も少ないことがわかった，愛知県で精神病床と 透析を持つ施設は僅か 15 箇所付すぎない.

今回は愛知県内を対象としたため, 愛知県の実態は 把握できたが，他府県の状況はどうなっているのか， その資料は極めて少なく情報がそしいのが現実であ る.

我々の今回行った調査の内容を, 同一診療圈に属す る施設で共有し，この問題を全体として解決するため の資料の一部とする必要性を痛感している。また, 他 府県の情報を得るため, 全国規模での実態調査が望ま れる。

\section{まとめ}

精神障害既往歴をもつ患者のメンタルサポートに は, 精神疾患の専門知識を持つスタッフや精神科専門 医との密な連携が必要となってくる，精神症状の増悪 時には, より安全に透析を行うため, 他の職種間の情 報交換を十分行い，診療チームの作成が必要である。 今後望まれる医療情報化社会においては, 精神障害を 含めたいかなる合併症を有する患者の発生時にも対応 可能なネットワークを早急に作成していく必要がある と考えられた。

謝辞: 今回アンケートの主旨に御理解頂き, 御支援と御 援助を賜った愛知県透析医会の諸先生と回答に御協力頂き ました愛知県下の透析施設の皆様の御協力に感謝します。

\section{文献}

1）荒木冨士夫：リエゾン・コンサルテーション精神医 学. 臨牀透析 9:7-10, 1993

2) 天野直二：透析患者の脳血管性痴呆。臨牀透析 $10: 57$ -63, 1994

3) 福井博義：リエゾン (連携) 精神医学 (2) 地域の腎 (透 析）センターなどとの連携一透析患者の転院を中心に （a）腎（透析）センターの医師からの希望. 臨牀透析 $9: 19-23,1993$

4）佐藤喜一郎：透析患者の脳障害 (4) 精神心理学的問題. 臨牀透析 $13: 99-105,1997$

5）大神ヨシ子, 岡崎陽子：精神障害患者の看護。臨牀透 析 $10: 71-74,1994$

6) 小家秋子：リエゾン (連携) 精神医学 (2) 地域の腎 (透 析）センターなどとの連携一透析患者の転院を中心に （b）腎（透析）センターの看護婦からの希望. 臨牀透 析 $9: 25-29,1993$ 